\title{
Chryseomonas luteola: an unusual clinical infection mimicking a mediastinal malignant lymphoma
}

This article was published in the following Dove Press journal:

Pathology and Laboratory Medicine International

26 November 2010

Number of times this article has been viewed

\author{
Gaia Goteri' \\ Gerry M Dorrestein ${ }^{2}$ \\ Ester Manso 3 \\ Federica Giantomassi' \\ Corrado Rubini' \\ Antonio Zizzi' \\ Giovanni Pomponio 4 \\ 'Department of Neurosciences, \\ Section of Pathologic Anatomy \\ and Histopathology, Polytechnic \\ University of Marche-United \\ Hospitals, Ancona, Italy; ${ }^{2}$ Diagnostic \\ Pathology Laboratory, Dutch \\ Research Institute for Avian and \\ Exotic Animals (NOIVBD), Veldhoven, \\ The Netherlands; ${ }^{3}$ Microbiology \\ Laboratory, ${ }^{4}$ Medical Clinic, United \\ Hospitals, Ancona, Italy
}

\begin{abstract}
Chryseomonas luteola is an infrequent human pathogen. We describe a case of mediastinal location showing Splendore-Hoeppli phenomenon in the abscess clinically mimicking a malignant lymphoma.
\end{abstract}

Keywords: Chryseomonas luteola, mediastinal lymphoma, botryomycosis, diagnosis

\section{Introduction}

Botryomycosis, initially described by Bollinger in 1870 in a pulmonary nodule in a horse, ${ }^{1}$ is a chronic suppurative infectious disease characterized by the presence of eosinophilic fungus-like granules in abscesses, displaying Splendore-Hoeppli phenomenon and mimicking fungal infections. ${ }^{2}$ Instead of fungi, these sulfur granules contain bacteria that may be highlighted by Gram or Giemsa staining. The pathogenesis of botryomycosis is not known, but it may be related to the dose and attenuate virulence of the bacteria, to an immune dysfunction or an altered inflammatory response caused by inadequate antibiotic therapy. ${ }^{3}$ The more frequent agents causing botryomycosis are Staphylococcus aureus (40\%) and Pseudomonas aeruginosa (20\%); less frequently, other agents might be involved. ${ }^{4,5}$ Both cutaneous and visceral forms of botryomycosis are known; particularly, visceral diseases may cause serious differential diagnostic problems with malignancies. ${ }^{6}$ All organs might be affected, and the disease has been described in the liver, kidney, brain, prostate, orbit, tongue, ear, bowel, and lung. We herein describe a striking thoracic botryomycosis mimicking mediastinal lymphoma in a young patient due to an uncommon bacterium.

\section{Case report}

A 16-year-old girl affected by autoimmune thrombocytopenia and on high-dose steroid therapy (average dose: $0.7 \mathrm{mg} / \mathrm{kg} /$ day for 1 year) presented with a 1 -month history of fever and evidence on computed tomography scan of a mediastinal mass extending into the lung (Figure 1). Slight pericardial effusion was also found, but no investigations on the pericardial effusion were done. The patient had also leucopenia with lymphocytopenia: the whole presentation was considered very suspicious for a mediastinal lymphoma, more than for a germ cell tumor. The patient underwent surgery for histological diagnosis of the mass. Fresh samples were sent for intraoperative diagnosis to evaluate the adequacy of tissue for diagnosis: on frozen section, an abundant inflammatory infiltration of neutrophils was disclosed and a diagnosis
Correspondence: Gaia Goteri

Department of Neurosciences, Section of Pathologic Anatomy and Histopathology, Polytechnic University of Marche-United Hospitals, Via Conca 7I, 60020 Torrette di Ancona, Italy

Tel +39 07| 59648II

Fax +39 07I 889985

Email g.goteri@univpm.it 


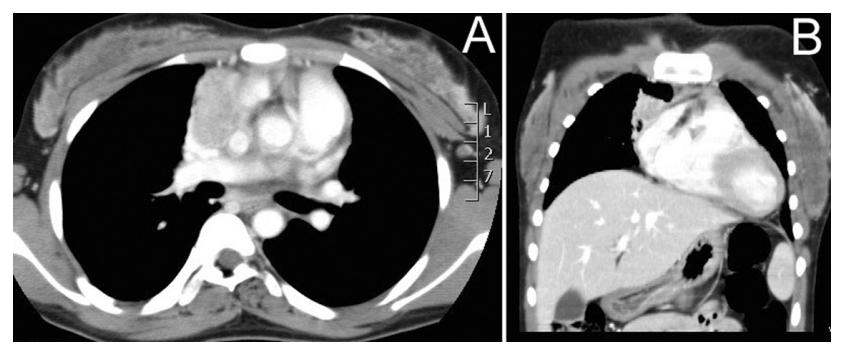

Figure I Computed tomography thorax reveals the presence of an antero-lateral mediastinal mass in the two projections (A, B).

of mediastinal abscess was done as there was no evidence of neoplastic cells with the appearance of Reed-Sternberg cells or Hodgkin cells featuring a neutrophilic-rich variants of Hodgkin or anaplastic large cell lymphomas. Due to the intraoperative diagnosis, pathological tissue was sent fresh for microbiologic investigations also. On formalin-fixed and paraffin-embedded sections, histological examination revealed a diffuse granulomatous suppurative process showing the so-called Splendore-Hoeppli phenomenon: bundles of peculiar bacillary structures were frequently embedded in an eosinophilic substance, which formed a peripheral ring (Figure 2A). The microorganisms stained blue with Giemsa (Figure 2B), whereas the substance was strongly periodic acid-Schiff positive (Figure 2C). Microbiological cultures from the tissue yielded growth of lobated colonies, with a 'fried egg' morphology and a cheese-like texture, identified as Chryseomonas luteola. A final diagnosis of botryomycosis due to C. luteola was rendered. The patient immediately started treatment with meropenem $70 \mathrm{mg} / \mathrm{kg}$ tid and cyprofloxacin $500 \mathrm{mg}$ bid for 6 weeks and rapidly recovered. The possible source of infection was not found: history revealed that the patient lived in the countryside in close contact with many domestic animals.

\section{Discussion}

C. luteola is an aerobic, motile, nonspore-forming gramnegative rod, ubiquitous in water and soil, which produces a characteristic yellow pigment. ${ }^{7}$ First described by Tatum and coworkers in $1974,{ }^{8}$ it has been reported in few publications ${ }^{9-23}$ as the causing agent mainly of bloodstream infections associated with intravenous indwelling catheters, prosthetic valve endocarditis, foreign bodies, pancreatitis, and cutaneous abscesses. Rarely, nonbacteremic cases have been described as postneurosurgical infections, fatal meningitis, peritonitis complicating appendicitis or peritoneal dialysis catheters, femur abscess, subphrenic abscess, endolphalmitis, facial cellulitis, leg ulcer in a patient with sickle disease, and hand infection. ${ }^{10-20}$ The use of steroids, immunodepression, the presence of a foreign body, and postsurgical instability have been suggested to predispose to infection with $C$. luteola. Infections are therefore more frequently nosocomially acquired than community acquired. In our patient, no previous history of catheterism or surgery was present, but we think that previous steroid therapy for thrombocytopenia could have predisposed the infection. As in our case, the outcome of infection caused by C. luteola is usually good. The organism is generally resistant to first- and second-generation cephalosporins, but sensitive to thirdgeneration cephalosporins, aminoglycosides, ureidopenicillins, and quinolones, with variable sensitivity to ampicillin and tetracycline.

Finally, we would point out that a pulmonary infection similar to that in humans is regularly found in ferrets (Mustela putorius furo), a small carnivorous animal that is becoming increasingly popular in Western countries as a pet animal. Although our patient did not keep such an animal, ferrets and squirrels are numerous in the area where the patient lived and we cannot exclude a possible contact with contaminated water or soil or with other animals. Animals can be a potential

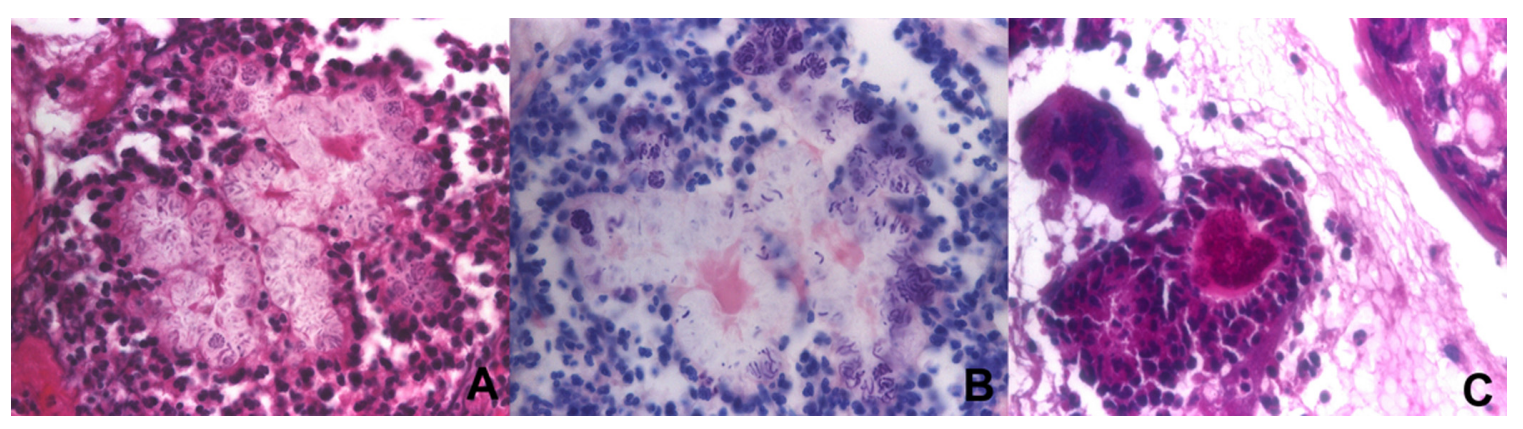

Figure 2 A) Histological section revealed a suppurative inflammation with the so-called Splendore-Hoeppli phenomenon with neutrophils surrounding bundles of peculiar bacillary structures embedded in an eosinophilic substance, which formed a peripheral ring. B) The microrganisms were stained blue with Giemsa. C) The substance was strongly periodic acid-Schiff positive (250x original magnification). 
source for uncommon infections, especially in contact with immunocompromised patients.

\section{Disclosure}

The authors report no conflict of interest in this work.

\section{References}

1. Bollinger O. Mycosis der Lunge beim Pferde. Virchow's Arch Pathol Anat. 1870;49(4):583-586.

2. Rodig SJ, Dorfman DM. Splendore-Hoeppli phenomenon. Arch Pathol Lab Med. 2001;125(11):1515-1516.

3. Leong Y-L, Li Y-S, Chang YL, Lee Y-C. Primary pulmonary botryomycosis with multiple adjacent organ involvement mimicking mucosa-associated lymphoid tissue lymphoma. J Formos Med Assoc. 2005;104(10):744-747.

4. Coelho WS, Diniz LM, Souza Filho JB. Cutaneous botryomycosis: case report. An Bras Dermatol. 2009;84(4):396-399.

5. Brunken RC, Lichon-Chao N, van der Broek H. Immunologic abnormalities in botryomycosis. A case report with review of the literature. J Am Acad Dermatol. 1983;9(3):428-434.

6. Carson HJ, Perkins JT. Visceral botryomycosis in a case of Erysipelothrix rhusiopathiae endocarditis. Hum Pathol. 2005;36(1):117-119.

7. Rahav G, Simhon A, Mattan Y, Moses AE, Sacks T. Infections with Chryseomonas luteola (CDC group Ve-1) and Flavimonas oryzhabitans (CDC group Ve-2). Medicine (Baltimore). 1995;74(2):83-88.

8. Tatum HW, Ewing WH, Weaver RE. Miscellaneous Gram-negative bacteria. In: Lennette EH, Spaulding EH, Truant JP, editors. Manual of Clinical Microbiology, 2nd ed. Washington, DC: American Society for Microbiology; 1974:270-294.

9. O’Leary T, Fong IW. Prosthetic valve endocarditis caused by group Ve-1 bacteria (Chromobacterium typhiflavum). J Clin Microbiol. 1984; 20(5):995.

10. Connor BJ, Kopecky RT, Frymoyer PA, Forbes BA. Recurrent Pseudomonas luteola (CDC group Ve-1) peritonitis in a patient undergoing continuous peritoneal dialysis. J Clin Microbiol. 1987;25(6): 1113-1114.
11. Engel JM, Alexander FS, Pachucki CT. Bacteremia caused by CDC group Ve-1 in previously healthy patient with granulomatous hepatitis. J Clin Microbiol. 1987;25(10):2023-2024.

12. Freney J, Hansen W, Etienne J, Vandenesch F, Fleurette J. Postoperative infant septicemia caused by Pseudomonas luteola (CDC group Ve-1) and Pseudomonas oryzihabitans. J Clin Microbiol. 1988;26(6):1241-1243.

13. Hawkins RE, Moriarty RA, Lewis DE, Oldfield EC. Serious infections involving the CDC group Ve bacteria Chryseomonas luteola and Flavimonas oryzihabitans. Rev Infect Dis. 1991;13(2):257-260.

14. Kostman JR, Soloman F, Fekete T. Infections with Chryseomonas luteola (CDC group Ve-1) and Flavimonas oryzihabitans (CDC group Ve-2) in neurosurgical patients. Rev Infect Dis. 1991;13(2): 233-236.

15. Rastogi S, Sperber SJ. Facial cellulitis and Pseudomonas luteola bacteremia in an otherwise healthy patient. Diagn Microbiol Infect Dis. 1998;32(4):303-305.

16. Ghosh SK. A rare infection caused by Chryseomonas luteola. $J$ Infect. 2000;41(1):109-110.

17. Chang JS, Chou C, Lin YC, Lin PJ, Ho JY, Hu TL. Kinetic characteristics of bacterial azo-dye decolourization by Pseudomonas luteola. Water Res. 2001;35(12):2841-2850.

18. Tsakris A, Hassapopoulou H, Skoura L, Pournaras S, Douboyas J. Leg ulcer due to Pseudomonas luteola in a patient with sickle cell disease. Diagn Microbiol Infect Dis. 2002;42(2):141-143.

19. Chihab W, Alaoui A, Amar M. Chryseomonas luteola identified as the source of serious infections in a Moroccan University Hospital. J Clin Microbiol. 2004;42(4):1837-1839.

20. Jayagopal S, Berry MG, Ross G, Howcroft AJ. Hand infection caused by Chryseomonas luteola. Br J Plast Surg. 2004;57(7):694-695.

21. Dalamaga M, Karmaniolas K, Chavelas C, Liatis S, Matekovits H, Migdalis I. Pseudomonas luteola cutaneous abscess and bacteraemia in a previously healthy man. Scand J Infect Dis. 2004;36(6-7): 495-497.

22. Uy HS, Leuenberger EU, de Guzman BB, Natividad FF. Chronic, postoperative Pseudomonas luteola endophthalmitis. Ocul Immunol Inflamm. 2007;15(4):359-361.

23. Gaschet A, Engrand C, Piau C, et al. Multiple brain abscesses caused by Pseudomonas luteola. Pediatr Infect Dis J. 2009;28(12):1144-1146.
Pathology and Laboratory Medicine International

\section{Publish your work in this journal}

Pathology and Laboratory Medicine International is a peer-reviewed, open access journal focusing on innovative basic research and translational research related to pathology or human disease. The journal includes original research, updates, case reports, reviews and commentaries on current controversies. The Academic Sponsor

\section{Dovepress}

of this journal is the Chinese American Pathology Association (CAPA). The manuscript management system is completely online and includes a very quick and fair peer-review system. Visit http://www.dovepress.com/testimonials.php to read real quotes from published authors. 